\title{
Identification and characterisation of microsatellite markers in narrow barred Spanish mackerel Scomberomorous commerson (Lacepede, 1800)
}

\author{
P. R. DIVYA ${ }^{1}$, N. VINEESH ${ }^{2}$, A. KATHIRVELPANDIAN ${ }^{1}$, C. MOHITHA ${ }^{1}$, V. S. BASHEER ${ }^{1}$, \\ A. GOPALAKRISHNAN ${ }^{2}$ AND J. K. JENA ${ }^{3}$ \\ ${ }^{1}$ Peninsular and Marine Fish Genetic Resources Centre, ICAR-National Bureau of Fish Genetic Resources, \\ ICAR-CMFRI Campus, Kochi - 682 018, Kerala, India \\ ${ }^{2}$ ICAR-Central Marine Fisheries Research Institute, Kochi - 682 018, Kerala, India \\ ${ }^{3}$ Krishi Anusandhan Bhawan - II, Indian Council of Agricultural Research, Pusa, New Delhi - 110 012, India \\ e-mail:divyanbfgr@gmail.com
}

\begin{abstract}
Narrow barred Spanish mackerel, Scomberomorus commerson (Lacepede 1800) is one of the commercially important fish in Indian waters. For sustainable management of the species, it is necessary to understand the genetic stock structure of the species. Accurate delineation of genetic stock structure can be achieved using nuclear microsatellite markers. A study was carried out to identify and validate polymorphic microsatellite markers in $S$. commerson using information available from closely related fish species. The study could identify 10 polymorphic microsatellite loci which can be effectively utilised for identifying genetic stock structure of the species. Validation of the identified loci was also done by testing the loci in natural populations of the species. The findings of the present study will be useful in devising stock-specific management measures for conservation and sustainable utilisation of this commercially important fish species in Indian waters.
\end{abstract}

Keywords: Cross species amplification, Genetic diversity, Polymorphic microsatellite markers, Population genetic structure, Scomberomorus commerson

\section{Introduction}

Narrow barred Spanish mackerel, Scomberomorus commerson (Lacepede 1800), (Family: Scombridae) is one of the commercially important fish species in Indian waters having high demand in the domestic and the export markets. It is an epipelagic species, distributed widely across Red Sea, Indo-West Pacific and the Mediterranean Sea (Eschmeyer and Fricke, 2016). S. commerson forms an important fishery in Indian waters with a total catch of 39,362 t (CMFRI, 2015). Considering overexploitation and increased fishing pressure on populations over its distribution range in the Indian Ocean, this species is categorised as "Near Threatened" in the IUCN Redlist assessment (Collette et al., 2011). Considerable uncertainty remains regarding the stock structure and the total catch of $S$. commerson in the Indian Ocean region. Currently, no information on quantitative stock assessment is available for this species for the entire Indian Ocean, except for the report on preliminary stock status by Indian Ocean Tuna Commission (IOTC, 2013).

Stock structure data is vital for devising any stock specific management for sustainable utilisation and conservation of fish species. Genetic stock structure can be efficiently accessed through nuclear polymorphic microsatellite markers (Wright and Bentzen, 1994). Microsatellites are short tandemly arrayed repeats of 1-6 nucleotides that occur at high frequency in the nuclear genomes of most taxa. These repeat regions are flanked by regions of non-repetitive unique DNA sequences (Tautz, 1989). Developing polymorphic microsatellites for a particular species is costly and time consuming. Fortunately, flanking region similarities between closely related species reduces considerable effort for developing polymorphic microsatellite markers for population genetic analysis (cross-species amplification). This cost-effective alternative for developing polymorphic microsatellite markers is comparatively easier and has been successfully carried out in many fish species for population studies (Lal et al., 2004; Mohitha et al., 2014; Kathirvelpandian et al., 2014). In the present study, development of 11 microsatellite markers in $S$. commerson through cross-species amplification was carried out from closely related species such as Scomber australasicus, Scomber japonicus, Scomberomorus cavalla and Rastrelliger kanagurta. The study also attempted to validate the utility of microsatellite markers in revealing the population genetic structure of commercially important fish species. 


\section{Materials and methods}

\section{Sample collection and DNA isolation}

Tissue samples of $S$. commerson were taken from specimens collected from landing centers of Vishakhapatnam in Andhra Pradesh and Chennai in Tamil Nadu on the east coast of India and Kochi in Kerala and Veraval in Gujarat on the west coast of India, during December 2013 to September 2014 (Table 1). Twenty tissue samples each were collected from all the sampling locations and preserved in 95\% ethyl alcohol. DNA isolation was carried out following Miller et al. (1988) with minor modifications.

Table 1. Sampling sites with geographical co-ordinates

\begin{tabular}{lll}
\hline Location & Geographical co-ordinates & Sample size \\
\hline Vishakhapatnam (Andhra Pradesh) & $17.6883^{\circ} \mathrm{N}, 83.2186^{\circ} \mathrm{E}$ & 20 \\
Chennai (Tamil Nadu) & $13.0839^{\circ} \mathrm{N}, 80.2700^{\circ} \mathrm{E}$ & 20 \\
Kochi (Kerala) & $9.9312^{\circ} \mathrm{N}, 76.2673^{\circ} \mathrm{E}$ & 20 \\
Veraval (Gujarat) & $20.9000^{\circ} \mathrm{N}, 70.3700^{\circ} \mathrm{E}$ & 20
\end{tabular}

\section{Identification of polymorphic microsatellite markers}

Microsatellite information of the closely related species were collected from GenBank (National Centre for Biotechnology Information - NCBI; www.ncbi.nlm. nih.gov) and other published resources. For cross-species amplification, a total of 28 microsatellite primers (Table 2) comprising 10 from S. australasicus (Tang et al., 2009), 8 from $S$. japonicus (Cha et al., 2010), 4 from $S$. cavalla (Broughton et al., 2002) and 6 from R. kanagurta (Candy et al., 2013, unpublished) were used.

\section{PCR amplification}

PCR amplifications were carried out following standard protocol in $25 \mu \mathrm{l}$ reactions containing $2.5 \mu \mathrm{l}$ of $10 \times$ PCR buffer $(100 \mathrm{mM}$ Tris, $\mathrm{pH} 8.8,500 \mathrm{mM} \mathrm{KCl}$, $25 \mathrm{mM} \mathrm{MgCl}_{2}, 0.8 \%$ (v/v) (Fermentas, Burlington, Canada) and $1.5 \mathrm{U}$ of Taq DNA polymerase (Fermentas), $200 \mu \mathrm{M}$ of each dNTPs (dATP, dCTP, dGTP and dTTP) (Fermentas), 20 pmol of each primer and $20 \mathrm{ng}$ of genomic DNA. The amplification conditions were: $95^{\circ} \mathrm{C}$ for $5 \mathrm{~min}$ followed by 34 cycles at $94^{\circ} \mathrm{C}$ for $30 \mathrm{sec}$, annealing (Table 3) for $30 \mathrm{sec}$ and $72^{\circ} \mathrm{C}$ for $30 \mathrm{sec}$, with final extension of $72^{\circ} \mathrm{C}$ for $10 \mathrm{~min}$. PCR products were stored at $4^{\circ} \mathrm{C}$. After amplification, $8 \mu \mathrm{l}$ of PCR products were electrophoresed on $8 \%$ non-denaturing polyacrylamide (19:1, acrylamide: bis-acrylamide) gels (size $10 \times 10.5 \mathrm{~cm}$, Amersham Bioscience, Piscataway, USA). The gels were silver stained (Silver Staining kit, Amersham Biosciences) to visualise microsatellite loci and allele patterns using standard DNA ladder (pBR 322/ MspI digest). Cross-priming standardisation was carried out with the samples collected from different locations
Table 2. Details of microsatellite primers used for cross-priming in $S$. commerson

\begin{tabular}{|c|c|c|c|}
\hline Resource species & Locus code & Accession no. & References \\
\hline \multirow[t]{10}{*}{ Scomber australasicus } & Sa42 & EF494258 & \multirow[t]{10}{*}{ Tang et al. (2009) } \\
\hline & Sa2068 & EF494259 & \\
\hline & Sa2344 & EF494261 & \\
\hline & Sa2599 & EF494262 & \\
\hline & Sa2657 & EF494263 & \\
\hline & Sa2683 & EF494264 & \\
\hline & Sa2769 & EF494265 & \\
\hline & Sa2770 & EF494266 & \\
\hline & Sa2873 & EF494267 & \\
\hline & Sa3337 & EF494268 & \\
\hline \multirow{8}{*}{ Scomber japonicus } & KSj3 & EF109782 & \multirow[t]{8}{*}{ Cha et al. (2010) } \\
\hline & $\mathrm{KSj} 4$ & EF109783 & \\
\hline & $\mathrm{KSj} 12$ & EF109784 & \\
\hline & KSj14 & EF109785 & \\
\hline & KSj18 & EF109786 & \\
\hline & $\mathrm{KSj} 22$ & EF109787 & \\
\hline & KSj26 & EF109789 & \\
\hline & $\mathrm{KSj} 27$ & EF109789 & \\
\hline \multirow{4}{*}{ Scomberomorous cavalla } & Sca37 & & \multirow[t]{4}{*}{ Broughton et al. (2002) } \\
\hline & Sca44 & & \\
\hline & Sca8 & & \\
\hline & Sca30 & & \\
\hline \multirow[t]{6}{*}{ Rastrelliger kanagurta } & Raka36 & & \multirow[t]{6}{*}{ Candy et al. (2013) } \\
\hline & Raka45 & & \\
\hline & Raka26 & & \\
\hline & Raka46 & & \\
\hline & Rakal & & \\
\hline & Raka2 & & \\
\hline
\end{tabular}

for optimising annealing temperature. The PCR products of polymorphic microsatellite loci were sequenced in ABi 3730 DNA sequencer (Applied Biosystems) in the sequencing facility to confirm the occurrence of the repeat units. Genotyping of polymorphic microsatellite loci was carried out manually.

Data analysis

The parameters like number of alleles per locus $\left(\mathrm{N}_{\mathrm{A}}\right)$, observed $(\mathrm{Ho})$ and expected $(\mathrm{He})$ heterozygosities and exact P-tests for conformity to Hardy-Weinberg Equilibrium (probability and score test) using Markov Chain method were estimated using GENEPOP version 3.3d (Raymond and Rousset, 1998) with parameters, dememorisation $=1000$; batches $=10$ and iterations $=100$; and based upon a null hypothesis of random union of gametes. The significant criteria were adjusted for the number of simultaneous tests using sequential Bonferroni technique (Rice, 1989). Presence of null alleles was tested to rule out false homozygotes. The expected frequency of null alleles was calculated using MICRO-CHECKER 2.2.3 (Van Oosterhout et al., 2004) and all the genotypes of the 
loci showing deviation from Hardy-Weinberg equilibrium were tested for presence of null alleles. The inbreeding coefficient $\left(\mathrm{F}_{\text {IS }}\right)$ was estimated through estimator of Weir and Cockerham (1984) using GENEPOP version $3.3 \mathrm{~d}$ (Raymond and Rousset, 1998). An analysis of molecular variance (AMOVA) was also carried out to examine the amount of genetic variation partitioned within and among populations using Gen Alex version 6.5 (Peakall and Smouse, 2012). Samples collected from east coast and west coast were considered as separate groups for analysis.

\section{Results and discussion}

Cross-species amplification can be used as an ideal tool to identify a set of markers without developing specific primers for each species studied, which helps in saving money and time (Galbusera et al., 2000). Flanking region similarities or conserved regions between closely related species helps to reduce the effort required for designing primers in other marine fish species (Kathirvelpandian et al., 2014; Mohitha et al., 2014). The success of cross-species amplification is higher for species with long generation time, mixed or out crossing breeding system and smaller genome size compared to the resource species (Barbara et al., 2007).
A total of 28 microsatellite primer pairs were tested for cross-species amplification and out of these, 11 primers were successfully amplified in $S$. commerson. The percentage of amplification rate was $39.2 \%$. Out of the 11 primers, Raka 36 was found to be monomorphic, and was consequently excluded from the analysis. The characteristics of the developed primers are given in Table 3. The optimum annealing temperature was different in $S$. commerson from that reported in the resource species.

Criteria for cross-amplification success are amplification of band in the expected size range and presence of polymorphism. The primers which got amplified in the present study were in the same range of resource species. The degree of polymorphism was determined at each locus. The range of annealing temperature was from $48^{\circ} \mathrm{C}$ to $59^{\circ} \mathrm{C}$, similar to earlier studies (Gopalakrishnan et al., 2004; Mohitha et al., 2014). The repeat motif, size range and annealing temperature obtained in $S$. commerson are given in Table 3. Sequence information of the PCR products confirmed the microsatellite repeat motifs and the sequences were submitted to Genbank (Table 3). Most of the loci (9 loci) were perfect dinucleotide repeats. Remaining were tetra and trinucleotide repeats.

Table 3. Characteristics of selected microsatellite loci in S. commerson

\begin{tabular}{|c|c|c|c|c|c|c|}
\hline \multirow{2}{*}{ Locus } & \multirow{2}{*}{$\begin{array}{l}\text { Repeat motif in } \\
\text { resource species }\end{array}$} & \multirow{2}{*}{ Primer sequences } & \multicolumn{4}{|c|}{ S. commerson } \\
\hline & & & $\begin{array}{l}\text { Annealing } \\
\text { temperature } \\
\mathrm{Ta}\left({ }^{\circ} \mathrm{C}\right)\end{array}$ & Repeat motif & $\begin{array}{l}\text { Size range } \\
\text { (bp) }\end{array}$ & Accession no. \\
\hline Sa 2769 S. australasicus & $(\mathrm{AC})_{18}$ & $\begin{array}{l}\text { F-TTTTGCATTTTAAGCAGCTCAGT } \\
\text { R-GTGGTGGACACACACAGATTCAT }\end{array}$ & 56 & $(\mathrm{AC}) 9$ & $221-259$ & KP120688 \\
\hline Sa 2657 S. australasicus & $(\mathrm{CA})_{16}$ & $\begin{array}{l}\text { F-TGTCAGAGATGTAGCACATACGG } \\
\text { R-AGCATTATCTGGTGCTGTAAGGA }\end{array}$ & 56 & $(\mathrm{CG}) 8(\mathrm{AG}) 6$ & $240-328$ & KP120686 \\
\hline Sa 2068 S. australasicus & $(\mathrm{GGA})_{9}$ & $\begin{array}{l}\text { F-CAAGACATGACAGTAGGACATTGAC } \\
\text { R-AGATTGGGAGTTTGTAGGGGTAATA }\end{array}$ & 56 & $(\mathrm{AG}) 8$ & $146-176$ & KP120684 \\
\hline Sa2770 S. australasicus & $(\mathrm{CA})_{13}(\mathrm{CCT})_{3}$ & $\begin{array}{l}\text { F-AGAAATGAAAAGGGCTTTAAGGA } \\
\text { R-ACTGAGCTGCTTAAAATGCAAAA }\end{array}$ & 56 & (AC) 15 (CCT) 4 & $195-285$ & KP120689 \\
\hline Sca44 S. cavella & $(\mathrm{CTCG}) 2$ CTAT $(\mathrm{CTGT})_{5}$ & $\begin{array}{l}\text { F-ATGGCCAAATGGCACATAATCA } \\
\text { R-GGGCAGCTCCATGGGTCTGAGT }\end{array}$ & 58 & (TCTG) 8 & $169-175$ & KP120692 \\
\hline Sca-37 S. cavella & $(\mathrm{TG})_{8} \mathrm{AG}(\mathrm{TG})_{4} \mathrm{AG}(\mathrm{TG}) 4_{3}$ & $\begin{array}{l}\text { F-GCG CCGTGACTTTTTATTGCTC } \\
\text { R-CAACAATTAGTCGCAGCCCTAG }\end{array}$ & 58 & (GT) 10 & $154-168$ & KP120692 \\
\hline Raka -36 R. kanagurta & $(\mathrm{AGTG})_{10}$ & $\begin{array}{l}\text { F-TGTGTCTACACAGACAGAGGG } \\
\text { R-TAATCACTCTCGCTCGCTCG }\end{array}$ & 58 & $(\mathrm{AC}) 9$ & $101-153$ & KP120683 \\
\hline Sa2873 S. australasicus & $(\mathrm{CA})_{17}$ & $\begin{array}{l}\text { F- TCACACTGTGCAATAATCACTCC } \\
\text { R- TATTTGAGCAGCCTCAAGAAGAG }\end{array}$ & 59 & (TC)11 & $224-312$ & KP120690 \\
\hline Sa2683 S. australasicus & $(\mathrm{TG})_{17}(\mathrm{GA})_{15}$ & $\begin{array}{l}\text { F-CTGAGACACAGTGATGTTTGTCC } \\
\text { R- TGCATATAGCACGAAAAAGTCAT }\end{array}$ & 52 & (GT) 8 (TC) 8 & $223-297$ & KP120687 \\
\hline Sa2344 S. australasicus & $(\mathrm{GT}) 51$ & $\begin{array}{l}\text { F-CACAAAAGCTGCTTAACACACTCT } \\
\text { R- TCACACTCAGCAAAATGAAGTTTC }\end{array}$ & 48 & (TG)20 & $118-180$ & KP120684 \\
\hline KSj-26 S. japonicus & $(\mathrm{GT})_{13} \mathrm{AT}(\mathrm{GT})_{3}$ & $\begin{array}{l}\text { F-GGAGCATTTGACAACACTTAC } \\
\text { R-AGTCAGTTTTTGGTGGATGAG }\end{array}$ & 55 & $(\mathrm{GT}) 7$ & $174-196$ & KP120682 \\
\hline
\end{tabular}


The number of alleles per locus ranged from 9 (Sa 2873) to 26 (Sa 2769) with a mean of 15.5. The allele size was between 138 bp ( $\mathrm{Sa} 2657)$ and $300 \mathrm{bp}(\mathrm{KSj}$ 26). High microsatellite allele variation observed in the study was comparable with previous findings in marine fishes including Atlantic cod (8-46 alleles per locus) (Bentzen et al., 1996), silver pomfret (13-17 alleles per locus) (Archangi et al., 2013) and Atlantic salmon (5-41 alleles per locus; Nikolic et al., 2009). The expected and observed heterozygosities per locus and the estimated $\mathrm{Nm}$ (gene flow) ranged from 0.441 (Sa2068) to 0.875 (Sa2769); 0.175 (Sa2873) to 0.875 (Sa2769) and 0.859 (Sa 2683) to 4.636 (Sa 2770) respectively (Table 4). The observed allele frequencies in most of the loci did not show significant deviation ( $\mathrm{p}>0.05$ ) from Hardy-Weinberg
Table 5. F-Statistics and estimates of $\mathrm{Nm}$ over all populations for each locus in S. commerson

\begin{tabular}{lllll}
\hline Locus & $\mathrm{F}_{\text {IS }}$ & $\mathrm{F}_{\text {IT }}$ & $\mathrm{F}_{\text {ST }}$ & $\mathrm{Nm}$ \\
\hline SA2873 & 0.694 & 0.745 & 0.168 & 1.235 \\
KSj26 & 0.691 & 0.743 & 0.169 & 1.225 \\
Sa2344 & 0.358 & 0.49 & 0.206 & 0.966 \\
Sa2683 & 0.188 & 0.371 & 0.225 & 0.859 \\
Sa2769 & 0 & 0.068 & 0.068 & 3.415 \\
SCA44 & -0.012 & 0.15 & 0.16 & 1.312 \\
SCA37 & 0.4 & 0.472 & 0.12 & 1.835 \\
SA2657 & -0.15 & -0.053 & 0.084 & 2.72 \\
SA2068 & 0.207 & 0.318 & 0.141 & 1.528 \\
SA2770 & 0.264 & 0.302 & 0.051 & 4.636 \\
Mean & 0.264 & 0.361 & 0.139 & 1.973 \\
SE & 0.089 & 0.084 & 0.018 & 0.391 \\
\hline
\end{tabular}

Table 4. Summary of observed and expected number of alleles and heterozygosity statistics of 10 microsatellite loci in S.commerson

\begin{tabular}{llllllllllll}
\hline & & Sa 2873 & KSj 26 & Sa 2344 & Sa 2683 & Sa 2769 & Sca 44 & Sca 37 & Sa 2657 & Sa 2068 & Sa 2770 \\
\hline $\mathrm{Na}$ & Mean & 5.25 & 5.5 & 7 & 7 & 12.75 & 5.75 & 8.75 & 6.25 & 4 & 6.75 \\
& SE & 0.479 & 1.19 & 1.354 & 1.472 & 0.946 & 0.479 & 1.25 & 0.25 & 1.08 & 0.854 \\
$\mathrm{Ne}$ & Mean & 2.513 & 3.468 & 4.252 & 4.121 & 9.013 & 4.043 & 5.225 & 3.875 & 2.226 & 4.568 \\
& SE & 0.411 & 0.703 & 0.89 & 1.442 & 1.497 & 0.51 & 0.971 & 0.565 & 0.529 & 1.003 \\
$\mathrm{Ho}$ & Mean & 0.175 & 0.20 & 0.45 & 0.55 & 0.875 & 0.75 & 0.475 & 0.825 & 0.35 & 0.55 \\
& SE & 0.025 & 0.082 & 0.065 & 0.132 & 0.048 & 0.087 & 0.131 & 0.118 & 0.155 & 0.119 \\
$\mathrm{He}$ & Mean & 0.571 & 0.646 & 0.701 & 0.678 & 0.875 & 0.741 & 0.791 & 0.718 & 0.441 & 0.748 \\
& SE & 0.065 & 0.11 & 0.102 & 0.082 & 0.029 & 0.031 & 0.032 & 0.056 & 0.16 & 0.053 \\
\hline
\end{tabular}

equilibrium after sequential Bonferroni correction, which was similar to results in earlier studies (Kathirvelpandian et al., 2014; Mohitha et al., 2014). Wright's (1978) fixation index $\left(\mathrm{F}_{\mathrm{IS}}\right)$ is a measure of heterozygote deficiency or excess (inbreeding co-efficient) and the values of $\mathrm{F}_{\mathrm{IS}}$ for all populations ranged from -0.150 for the locus $\mathrm{Sa} 2657$ to + 0.694 for locus Sa 2873. In most of the loci, the value of $\mathrm{F}_{\text {IS }}$ was found to deviate significantly from zero, indicating a deficiency of heterozygotes. The presence of null alleles was checked using different algorithms in Micro Checker software and the estimated null allele frequency at all loci was not significant indicating the absence of null alleles.

Deviations from Hardy-Weinberg Equilibrium are often reported in marine fishes (Scribner et al., 1996; Selkoe and Toonen 2006). The $\mathrm{F}_{\mathrm{ST}}$ values of each loci for all populations ranged from 0.051 (Sa 2770) to 0.225 (Sa 2683) with a mean value of 0.139 (Table 5).

The mode of developing microsatellite markers through cross-species amplification was tested and validated in the current study. The results obtained from the present study authenticate that the microsatellite markers obtained through cross priming from closely related species are apt for population genetic analysis in S. commerson. In future, these primers can be effectively utilised for the stock identification of $S$. commerson for the successful management of the species.

\section{References}

Archangi, B., Bazrafshan, K.H., Ronagh, M.T., Savari, A. and Abadi, M.S.A. 2013. Population genetic structure of silver pomfret (Pampus argenteus) in Persian Gulf and Oman Sea, inferred from 11 microsatellite loci. World J. Fish Mar. Sci., 5: 227-32.

Barbara, T., Palma-Silva, Paggi, G. M., Bered, F., Fay, M. F. and Lexer, C. 2007. Cross species transfer of nuclear microsatellite markers: potential and limitations. Mol. Ecol., 16(18): 3759-3767.

Bentzen, P., Taggart, C. T., Ruzzante, D. E. and Cook, D. 1996. Microsatellite polymorphism and the population structure of Atlantic cod (Gadus morhua) in the north-west Atlantic. Can J. Fish Aquat. Sci., 53: 2706-2721.

Broughton, R. E., Stewart, L. B. and Gold, J. R. 2002. Microsatellite variation suggests substantial gene flow between king mackerel (Scomberomorus cavalla) in the western Atlantic Ocean and Gulf of Mexico. Fish. Res., 54: $305-316$

Cha, H. K., An, H. S., Choi, J. H., Kang, S., Park, J. Y. and Kim, K. K. 2010. Isolation and characterisation of polymorphic microsatellite markers for genetic analysis 
of chub mackerel (Scomber japonicus). Conserv. Genet. Resour., 2: 7-9.

CMFRI, 2015. Annual report 2015-16. Central Marine Fisheries Research Institute, Kochi, 534 pp.

Collette, B., Chang, S. K., Di Natale, A., Fox, W., Juan Jorda, M., Miyabe, N. and Nelson, R. 2011. Scomberomorus commerson. The IUCN Red List of threatened species. Version 2014.3. .www.iucnredlist.org. (Accessed 07 November 2014)

Eschmeyer, W. N. and Fricke, R. 2016. Catalog of fishes electronic version 2016. http://research.calacademy.org/ ichthyology/catalog/fishcatsearch.html (Accessed 02 September 2016)

Galbusera, P., Van, S. and Matthysen, E. 2000. Cross species amplicifcation of microsatellite primers in passerine birds. Conserv. Genet., 1: 163-168.

Gopalakrishnan, A, Musammilu, K. K., Muneer, P. M. A., Lal, K. K., Kapoor, D., Ponniah, A. G. and Mohindra, V. 2004. Microsatellite DNA markers to assess population structure of red-tailed barb, Gonoproktopterus curmuca. Acta. Zool. Sin., 50: 686-690.

IOTC 2013. Status of the Indian Ocean narrow-barred mackerel (COM: Scomberomorous commerson) resource. Indian Ocean Tuna Commission IOTC-2013-SC16-R(E), p. 207-312.

Kathirvelpandian, A., Gopalakrishnan, A., Lakra, W. S., Gopal Krishna, Sharma, Rupam, Musammilu, K. K., Basheer, V. S. and Jena, J. K. 2014. Microsatellite markers to determine population genetic structure in the golden anchovy, Coilia dussumieri. Biochem. Genet., 52: 296-309.

Lal, K. K., Chauhan, T., Mandal, A., Singh, R. K., Khulbe, L., Ponniah, A. G. and Mohindra, V. 2004. Identification of microsatellite DNA markers for population structure analysis in Indian major carp, Cirrhinus mrigala (HamiltonBuchanan, 1882). J. Appl. Ichthyol., 20: 87-91.

Miller, S. A., Dykes, D. D. and Polesky, H. F. 1988. A simple salting out procedure for extracting DNA from human nucleated cells. Nucleic Acids Res., 16(3): 1215.

Mohitha, C., Joy, L., Divya, P. R., Gopalakrishnan, A., Basheer, V. S., Koya, M. and Jena J. K. 2014. Characterisation of microsatellite markers in silver pomfret, Pampus argenteus (Perciformes: Stromateidae) through cross species amplification and population genetic applications. J. Genet., p. 1-5.

Nikolic, N., Feve, K., Chevalet, C., Hoyheim, B. and Riquet, J. 2009. A set of 37 microsatellite DNA markers for genetic diversity and structure analysis of Atlantic salmon Salmo salar populations. J. Fish. Biol., 74: 458-466.

Peakall, R. and Smouse, P. E. 2012. GenAlEx 6.5: genetic analysis in Excel. Population genetic software for teaching and research - an update. Bioinformatics, 28: 2537-2539.

Raymond, M. and Rousset, F. 1998 GENEPOP (ver. 3.1): A population genetics software for exact test and ecumenicism. J. Hered., 86: 248-249.

Rice, W. R. 1989. Analysing tables of statistical tests. Evol., p. 223-225.

Selkoe, K. A. and Toonen, R. J. 2006. Microsatellites for ecologists: a practical guide to using and evaluating microsatellite markers. Ecol. Lett., 9(5): 615-629.

Scribner, K. T., Gust, J. R. and Fields, R. L. 1996. Isolation and characteriation of novel salmon microsatellite loci: cross species amplification and population genetic applications. Can. J. Fish. Aquat. Sci., 53: 833-841.

Tang, C. Y., Tzeng, C. H., Chen, C. S. and Chiu, T. S. 2009 Microsatellite DNA markers for population genetic studies of blue mackerel (Scomber australasicus) and cross specific amplification in S. japonicus. Mol. Ecol. Resour., 9: 824-827.

Tautz, D. 1989. Hyper variability of simple sequences as a general source for polymorphic DNA markers. Nucleic Acids Res., 17(16): 6463-6471.

Van Oosterhout, C., Hutchinson, W. F., Wills, D. P. M. and Shipley, P. 2004. MICRO-CHECKER: software for identifying and correcting genotyping errors in microsatellite data. Mol. Ecol. Notes, 4: 535-538

Weir, B. S. and Cockerham, C. C. 1984. Estimating F-statistics for the analysis of population structure. Evol., 1358-1370.

Wright, S. 1978. Evolution and the genetics of population, variability within and among natural populations. Univ. Chicago Press, Chicago.

Wright, J. M. and P. Bentzen. 1994. Microsatellites: genetic markers for the future. Rev. Fish Biol. Fish., 4: 384-388. 